\title{
Do Irritations of Ads in Line Really Matter?
}

\author{
Wen-Yu Tsao ${ }^{1}$ \\ ${ }^{1}$ Department of Information Management, National Chin-Yi University of Technology, Taiwan, R. O. C. \\ Correspondence: Wen-Yu Tsao, No.57, Sec. 2, Zhongshan Rd., Taiping Dist., Taichung 41170, Taiwan (R.O.C.)
}

Received: March 19, 2019

Accepted: April 16, $2019 \quad$ Online Published: April 17, 2019

doi:10.5539/ibr.v12n5p53

URL: https://doi.org/10.5539/ibr.v12n5p53

\begin{abstract}
The Advertisings (ads) in LINE are the marketing promotions for enterprises to increase consumers' purchase intentions. People are likely to feel ads as unwelcome and irritating information and get unfavorable behavioral intentions. Information quality (IQ) and access convenience are the key factors of people satisfaction to decrease their unfavorable behavioral intentions including complaints, blockade, and negative WOM (NWOM). With data collected from a sample of 230 people in Taiwan, the results got the IQ and access convenience of ads impacted on unfavorable behavioral intentions through satisfaction and was particularly moderated by irritation with AMOS 21.0. The implications for theory and practice are discussed.
\end{abstract}

Keywords: information quality (IQ), access convenience, unfavorable behavioral intentions, irritation

\section{Introduction}

Social media allows internet users to directly communicate and interact with one another instantly (Correa $\mathrm{et} \mathrm{al}$. 2010). LINE is among the most popular and innovative information and communication social media platforms in Taiwan, and the number of LINE users in Taiwan is over 1.7 million as of 2018 ( $\mathrm{Su}, 2018$ ). Given the popularity of LINE, enterprises have created funny stickers with promotions to attract people who can respond with icons. This strategy is considered as viral marketing, whereby products are dramatically promoted by satisfied users through stickers in social media such as LINE. Information quality (IQ), system quality (SQ), and user satisfaction are vital factors of information system (IS) success (DeLone and McLean 1992), however the SQ of technologies is mature, therefore the paper focused on IQ. IQ includes accuracy, completeness, currency, and format which are important factors in a mobile data service environment (Kim and Han 2011). Studies have been conducted on IQ, aimed at web-based decision support systems (Bharati and Chaudhury 2004) and the design process documentation of quality management systems (Grudzień and Hamrol 2016). Satisfied users can enhance enterprises' competitive advantages (Tsao, 2014). Empirically studying both traditional ads and digital ads (such as mobile, pop-up, and pre-roll video ads) can help enterprises generate more attraction. Most ads are irritating to users who ultimately choose to avoid them (Cho 2004). Ads have also been found to irritate and affect bad feelings and shrink product value (Tsang et al. 2004; Okazaki 2004; Altuna and Konuk 2009; Ünal et al. 2011; Luna Cortés andRoyo Vela 2013). However, few studies have revealed that the effect of IQ on users' unfavorable behavioral intentions toward ads with mediated by satisfaction and moderated by irritation. Therefore, a better understanding of the "annoying" or "irritating" tactics used for advertisements is necessary for effective promotions. Unfavorable behavioral intention refers to the willingness of users to quit using or spend less time using an application, with specific unfavorable behaviors such as complaints, patronage reduction, and negative word of mouth (NWOM) (Smith andBolton 2002; Zeithaml et al. 1996). Following Singh andWilkes' (1996) definition, complaint refers to users' protests to ads, such as those in LINE, which can be in the form of releasing negative comments or further blockading of the message. Maxham III and Netemeyer (2002) explored the intention to complain in modeling customer perceptions of complaint handling over time. $\mathrm{Chu}$ (2011) found that the attitudes of college-aged Facebook group members toward viral advertising were higher than those of non-group members. Chuang et al. (2009) pointed out the effect of terminologies on attitudes toward advertisements and brands. Moreover, Wu (2013) and Wu andHuang (2015) linked complaint intentions in online shopping to satisfaction. Lee et al. (2016) found that users' ad skepticisms were negatively related to their attitude toward advertising and their intention to share on social media. Blockade is an act or means of sealing off a place to prevent goods or people from entering or leaving. In the context of the characteristics of LINE, blockade is used in place of patronage reduction in this study to approach a more 
relevant phenomenon regarding users' negative feelings. NWOM is defined as "any negative informal communication made by potential, actual, or former customers about a product or company, directed at other consumers about the ownership, usage, or characteristics of particular goods and services and/or their sellers via the Internet (Hennig-Thurau et al. 2004). In this paper, blockade refers to patronage reduction as an unfavorable behavioral intention.

In decision making, a high IQ leads to high user satisfaction (Bharati andChaudhury 2004). Kim and Han (2011) stated that IQ includes completeness and currency. They also pointed out that completeness and currency were important for user value in a mobile data service environment. Meanwhile, convenience also influences behavioral intentions through the mediating role of satisfaction in a Taiwanese leisure setting (Chang and Polonsky 2012). In this study, the factors influencing complaint, blockade, and NWOM as unfavorable behavioral intentions toward ads in LINE are chosen as outcomes. Bogart (1985) proposed that an ad has a negative function as an annoying or irritating medium. Hence, the following key questions are considered in this paper: (1) Do users' feelings about the ads' completeness and currency of information and ads access convenience in LINE influence their satisfaction? (2) Do users' perceptions of ads irritation have a moderating effect between satisfaction and unfavorable behavioral intentions? (3) Does the users' satisfaction have a mediating effect on unfavorable behavioral intentions? Therefore, this paper explores ads completeness, currency, and access convenience as the determinate factors that affect unfavorable behavioral intentions via satisfaction as a mediating variable and irritation as a moderating variable. The relationship diagram is illustrated in Figure 1 . The remainder of this paper is arranged as follows: Section 2 introduces the literature review and hypotheses; Section 3 presents the methodological research; Section 4 details the data analysis; and the last section, i.e., Section 5 offers a conclusion, including a discussion of the study's contributions and limitations and potential directions for future work.

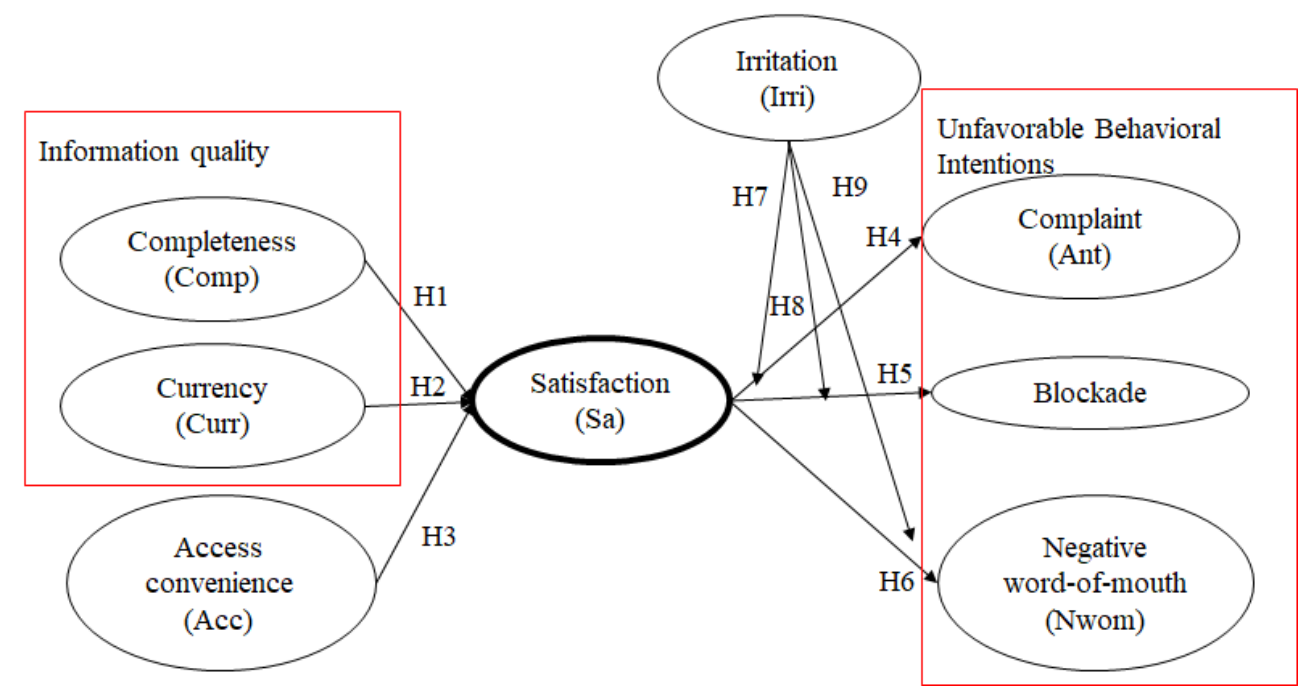

Figure 1. research model

Note 1. satisfaction is a mediator

Note 2. irritation is a moderator

\section{Literature Review and Hypotheses}

\subsection{Completeness and Currency of Information and Satisfaction}

IQ and user satisfaction are vital constructs of IS success (DeLone and McLean 1992). According to the definitions provided by Kim and Han (2011), completeness refers to the degree to which the ads in LINE produce all the required information, for example the price, quality, and country of manufacture. The currency is defined as the degree to which the ads in LINE are up to date. Kim and Han reported completeness and currency as IQ dimensions that are important factors in a mobile data service environment. A related research reports that completeness and currency influence satisfaction toward web-based decision support systems (Bharati and Chaudhury 2004), blogs (Hsieh et al. 2010), social networks (Zhang 2010), and logistics programs (Daud and Fang 2017). In market orientation, IQ and product price via social media to understand user behavior (Kohli and Jaworski 1990; Ngai et al. 2015). Erkan and Evans (2016) found that IQ had a relationship with consumers' purchase intentions in social media. Laumer et al. (2017) found that IQ was important in determining end-user 
satisfaction of enterprise content management system. Featuring highly required information and updated information in the ads in LINE can lead to high user satisfaction. Therefore, the completeness and currency of information regarding the ads in LINE have important effects on user satisfaction. On the basis of this logic, the following hypotheses are proposed in this paper:

Hypothesis 1: Users feel that the completeness of ads influences their satisfaction.

Hypothesis 2: Users feel that the currency of ads influences their satisfaction.

\subsection{Access Convenience and Satisfaction}

Access convenience saves the perceived time and effort about a service (Chang and Polonsky 2012). Convenience is an influential factor that leads to acceptance in a universal environment (Yoon and Kim 2007). Colwell et al. (2008) found that convenience is a vital factor of satisfaction in the context of personal cellular telephone and internet usage. Srivastava and Kaul (2014) found that convenience influenced shoppers' satisfaction for department store. Srivastava et al. (2015) found that women's access convenience determined satisfaction with maternal health care in developing countries. Ramanathan et al. (2017) found that the convenience of social media enhanced customer satisfaction. Considering the ad stickers in LINE, it has been found that access convenience directly affects user satisfaction. That is, the access convenience of ads in LINE has an important effect on user satisfaction. Thus, the following hypothesis is proposed in this paper:

Hypothesis 3: Users feel that ad access convenience influences their satisfaction.

\subsection{Irritation and Unfavorable Behavioral Intentions}

$\mathrm{Ha}$ (1996) defined irritation as the interruption of ads, which is annoying to users. Bauer and Greyser (1968) found that advertising is related to annoyance or irritation, and Edwards et al. (2002) studied four aspects of ads (timing of display, duration of ad, congruence with editorial content and perceived informational and entertainment value) that moderated perceptions of pop-up advertisements as irritation. Waller (2006) proposed brand attitude to be a factor of purchase intentions and built a response model for irritation toward advertising. He found that irritation was not significant in predicting brand attitudes in advanced to intention. However, Jin and Villegas (2006) reported that irritation leads to the avoidance of ads and is directly related to avoidance behaviors. Irritation is the crucial factor that leads consumers to avoid advertising while watching TV or streaming on YouTube (Loureiro 2018). Negative emotion and irritation are advertising experience motivations (Bronner and Neijens 2006) which have been related to social media (Rohm et al. 2013). Campbell et al. (2017) found that that less complexity of emotional ads characteristics increases skipping by failing to engage cognitive resources and therefore making people disposed to experience irritation. Unfavorable behavioral intention is defined as an indication that most users of an application are preparing to quit using or spend less time using an application (Scaglione 1988), such as LINE. The satisfaction of members in LINE is the vital factor determining what users intend to propagate (Tsao 2018). Such intentions include complaints, patronage reduction, and NWOM (Zeithaml et al. 1996; Smith and Bolton 2002). Users may utilize complaint to deal with their strong dissatisfaction (Singh and Widing 1991). Ads blockade is an incoming action of users to stop the ads. Negative words of mouth are negative feelings expressed by users regarding their experiences with ads in LINE, whereby the dissatisfied users intend to tell other users or potential users about their dissatisfaction (Litvin et al. 2008). Therefore, dissatisfied users will generate complaints and NWOM (Dubé et al. 1994; Stevens et al. 1995; Soriano 2002). More precisely, user dissatisfaction typically leads to complaints (Singh, 1988), negative feelings (Liu and Jang 2009), and NWOM (Richins 1983). Ducoffe (1996) stated that irritation is the main determinant of attitudes toward advertising on interactions between sellers and buyers. The majority of the studies indicated having none, little moderate experience (irritation) with ads in LINE. Irritation is viewed as a negative psychological feeling and represents consumers' avoidance (blockade) of advertising (Lin, 1999). It is a negative intrinsic motivator (Davis et al. 1992). The intrinsic motivation has a moderating effect between satisfaction and work performance (Kuvaas 2006). However, Nakagami et al. (2008) proved that the intrinsic motivation had no moderating effect between neurocognition and psychosocial functioning. Thus, low levels of satisfaction among users, moderated by irritation, can lead to a high degree of complaints, blockade, and NWOM. In terms of ads, irritation will aggravate the relationship between satisfaction and unfavorable behavioral intentions. The following hypotheses are proposed in this paper:

Hypothesis 4: Users who are satisfied with the ads in LINE have fewer complaints.

Hypothesis 5: Users who are satisfied with the ads in LINE express less intention to blockade.

Hypothesis 6: Users who are satisfied with the ads in LINE express fewer NWOMs.

Hypothesis 7: Users feel irritation has a moderating effect between their satisfaction and complaint. 
Hypothesis 8: Users feel irritation has a moderating effect between their satisfaction and blockade.

Hypothesis 9: Users feel irritation has a moderating effect between their satisfaction and NWOM.

\subsection{IQ, Satisfaction, and Unfavorable Behavioral Intentions}

Satisfaction is defined as users' positive feelings about their prior use of a product (Kang et al. 2009), and it has previously been reported to have a mediating effect on behavioral intentions (Finn et al. 2009), employees' financial performance (Chi and Gursoy 2009), purchase intentions (Udo et al. 2010), and loyalty at a Chinese telecom (Lai et al. 2009). Customer satisfaction partially mediates the effects of justice on WOM intent and purchase intent (Maxham III and Netemeyer 2002). Voorhees and Brady (2005) found that service quality had a significant and negative effect on future complaint intentions through satisfaction. Yen (2013) found that customer satisfaction had a mediating effect on usage intention in social networking sites. Fornell et al. (1996) and Olive (1997) had the similar propositions that consumer's satisfaction acted as a mediator between IQ and behavior intention. The satisfaction of festival visitors also exerts a mediating effect on quality of behavioral intentions (Cole and Illum 2006). Chang and Polonsky (2012) reported that access convenience influenced satisfaction and behavioral intentions in a Taiwanese leisure setting. They also found that satisfaction played a mediating role on intention. In other words, the completeness and currency of information and ads access convenience influence intention through satisfaction. Bai et al. (2008) found that the satisfaction of online Chinese visitors had a direct and positive impact on purchase intentions. Satisfaction will partially mediate the effects of perceived IQ on WOM intention in a website (Ha and Im 2012). Therefore, the completeness, currency, and access convenience of ads in LINE have significant effects on user satisfaction, and satisfaction has a mediating effect between the above factors and unfavorable behavioral intentions. Thus, the following hypotheses are proposed in this paper:

Hypotheses 10a,b,c: User satisfaction has mediating effects on the respective relationships among completeness, currency, access convenience, and complaint.

Hypotheses 11a,b,c: User satisfaction has mediating effects on the respective relationships among completeness, currency, access convenience, and blockade.

Hypotheses 12a,b,c: User satisfaction has mediating effects on the respective relationships among completeness, currency, access convenience, and NWOM.

\section{Methodology}

\subsection{Instrument Development}

The questionnaire used in the study contained eight constructs that were adopted and modified from prior studies to fit the scope of a web-based survey research form. Participants agreed to answer with statements using a five-point Likert-type scale (with 1 being "strongly disagree" and 5 being "strongly agree"). Questions regarding completeness and currency were adopted and modified from Kim and Han's (2011) items. Three items were provided to indicate the degree of users' feelings about the ads. Items evaluating access convenience and satisfaction were adopted and modified from Seiders et al.'s (2005) three items to determine the degree of users' feelings toward ads. Questions regarding users' perceptions of complaints were adopted and modified from Sanchez-Franco et al.'s (2009) three items to indicate the degree of users' feelings of pain and dissatisfaction. Items about users' perceptions of blockade were adopted and modified from Kim et al.'s (2009) three items to indicate the degree to which users were annoyed and willing to blockade the ads. Users' NWOM (three items) was measured using modified questions from Kalamas et al. (2008) to indicate the degree of users' negative feelings about ads. Finally, irritation about ads was determined using modified questions from Edwards et al.'s (2002) five items to measure the degree to which users feel annoyed about ads.

\subsection{Pretest and Pilot Test}

A pretest was used to assess the questionnaire in terms of its logical consistency, easiness to read, effectiveness of the sequence of items, and relevance. Specifically, the questionnaire was pretested for content and readability by 35 users with previous experiences in accessing ads using email surveys. No modifications were suggested by the pretest users; all the items of the questionnaire were regarded as being clear and easy to understand. A pilot study involving 50 MIS-graduated students at Chin-Yi University of Technology in Taiwan, all of whom had previous experiences of accessing ads in LINE, was then conducted to gain additional feedback about the questionnaire.

\section{Data Analysis}

In this paper, four criteria were used in the development of the scale: validity, action ability, efficiency, and 
generalizability. Unfavorable behavioral intentions are crucial with regard to users of ads in LINE, and they include complaints, blockade, and NWOM. The questionnaire used in this study had three questions about each of these subtypes of unfavorable behavioral intentions to provide a holistic view of unfavorable behavioral intentions regarding ads in LINE. A validity criterion referred to as construct validity, which included the assessments of convergent and discriminant validity, is discussed in Section 4.3. Finally, path analysis with AMOS was used to evaluate the hypotheses; the analysis is discussed in Section 4.4.

\subsection{Sample}

At the beginning of the survey, it was ensured that the respondents had experience using LINE. The sample data were collected through a web survey of 230 respondents who have experiences about ads in LINE. The survey was conducted for nine months from January 1st to September 30, 2016, in Taiwan at www.mysurvey.com.tw/ads. Three assistants were asked to distribute the link to the web survey through LINE, Facebook, and mail. In the first three months 168 responses were obtained, and 62 responses were obtained in the rest months. The gender-based response ratio was $43.5 \%$ males and $56.5 \%$ females. Approximately $51.3 \%$ of the participants were 31-40 years old. In terms of location, $57.8 \%$ lived in the five cities in the middle of Taiwan. The highest education level was college education (70.0\%). This education level of most of the respondents was mostly college; therefore, control variables were not included. The occupation with the most number of participants was related to the information industry (57.4\%). The participants' monthly incomes can be summarized as follows: $30.4 \%$ had a monthly income below NT\$30k; $25.7 \%$ had a monthly income between NT\$ 30k and 40k; $29.6 \%$ had a monthly income between NT\$40k and 50k; and $14.3 \%$ had a monthly income above NT\$ 50k. In terms of job experience, $1.7 \%$ reported less than 10 years, $10.4 \%$ reported $11-20$ years, $43.5 \%$ reported $16-20$ years, $43.5 \%$ reported $21-25$ years, and $0.9 \%$ reported above 26 years. The details are presented in Table 1.

Table 1. Demographic outline of respondents

\begin{tabular}{|c|c|c|c|}
\hline \multirow[b]{2}{*}{ Division } & \multirow{2}{*}{ item } & \multirow{2}{*}{ Frequency } & \multirow[b]{2}{*}{ Percent (\%) } \\
\hline & & & \\
\hline \multirow[t]{2}{*}{ gender } & male & 100 & 43.5 \\
\hline & female & 130 & 56.5 \\
\hline \multirow[t]{5}{*}{ age } & $<=30$ & 8 & 3.5 \\
\hline & $31 \sim 40$ & 118 & 51.3 \\
\hline & $41 \sim 50$ & 72 & 31.3 \\
\hline & $51 \sim 60$ & 22 & 9.6 \\
\hline & $>=61$ & 10 & 4.3 \\
\hline \multirow[t]{4}{*}{ location } & North & 20 & 8.7 \\
\hline & middle & 133 & 57.8 \\
\hline & south & 53 & 23.0 \\
\hline & east & 24 & 10.4 \\
\hline \multirow[t]{3}{*}{ education } & high & 15 & 6.5 \\
\hline & college & 161 & 70.0 \\
\hline & graduate & 54 & 23.5 \\
\hline \multirow[t]{4}{*}{ job } & Information & 132 & 57.4 \\
\hline & manufacturing & 49 & 21.3 \\
\hline & Service & 40 & 17.4 \\
\hline & Military and teacher & 9 & 3.9 \\
\hline \multirow[t]{4}{*}{ income } & $<=30000$ & 70 & 30.4 \\
\hline & $30001 \sim 40000$ & 58 & 25.7 \\
\hline & $40001 \sim 50000$ & 68 & 29.6 \\
\hline & $>=50001$ & 33 & 14.3 \\
\hline \multirow[t]{5}{*}{ Job experience } & $<10$ years & 4 & 1.7 \\
\hline & $11 \sim 15$ & 24 & 10.4 \\
\hline & $16 \sim 20$ & 100 & 43.5 \\
\hline & $21 \sim 25$ & 100 & 43.5 \\
\hline & $>26$ & 2 & 0.9 \\
\hline
\end{tabular}

\subsection{Nonresponse Bias}

Nonresponse bias was evaluated in two ways. First, following the procedure suggested by Armstrong and Overton (1977), tests were conducted for statistically significant differences between the responses of early (168 or $73 \%$ of the respondents) versus late respondents (62 or $27 \%$ of the respondents) using job segment and income per month in Taiwan. Chi-square tests comparing the categories across the two groups revealed no significant differences for the types of job $(F=0.915 ; p=0.340)$ or income per month $(F=0.032 ; p=0.858)$. The test also indicated no significant differences between the two groups (i.e., the types of job and income per month), thereby indicating no systematic nonresponse bias for the survey data. Second, the gender distribution of 
the respondents who returned questionnaires was compared with the gender distribution of the overall population (department of household registration, 2016,

(https://zh.wikipedia.org/zh-tw/\%E8\%87\%BA\%E7\%81\%A3\%E4\%BA\%BA\%E5\%8F\%A3); the percentages of males and females were almost equal), and no significant differences were found $(\chi 2=0.734, p=0.392)$. The result showed that the sample was generalized to the population.

\subsection{Reliability and Validity}

Reliability confirms internal consistency, and validity comprises convergent and discriminant validities. Cronbach's alpha of all the study constructs exceeded 0.7 , which is the recommended minimum for a reliability test in social science studies (Nunnally and Bernstein 1994). All the constructs passed the reliability test; therefore no item was dropped. The reliability values were as follows: completeness $(0.920)$, currency $(0.892)$, access convenience (0.874), irritation (0.910), satisfaction (0.938), complaints (0.895), blockade (0.907), and NWOM (0.896), as shown in Table 2. Following Podsakoff et al.'s (2003) suggestion, Harman's one-factor test was used in the present study to examine the common method bias, in which either a single factor will emerge from factor analysis or one general factor will account for the majority of covariance among measures. The first factor explains under half of the variance $(23.137 \%)$ even where common method bias does not exist in reality (Ylitalo 2009). The composite reliability (CR) and average variance extracted (AVE) of the study constructs were as follows: completeness $(0.955,0.875)$, currency $(0.880,0.711)$, access convenience $(0.887,0.724)$, irritation $(0.909,0.667)$, satisfaction $(0.882,0.713)$, complaint $(0.816,0.598)$, blockade $(0.824,0.610)$, and NWOM $(0.899,0.749)$. Both the CR and AVE of all constructs exceeded the suggested thresholds (0.6 and 0.5 , respectively). These results indicate that the convergent validity of the scale was good (Fornell and Larcker 1981). Furthermore, as shown in Table 3, the square root of each construct's AVE exceeded its corresponding correlation coefficients with other factors, indicating good discriminant validity.

Table 2. Results for overall measurement model $(n=230)$

\begin{tabular}{|c|c|c|c|c|c|c|c|c|c|c|c|}
\hline items & 1 & 2 & 3 & 4 & 5 & 6 & 7 & 8 & $\alpha$ & $\mathrm{CR}$ & AVE \\
\hline comp1 & 0.000 & 0.134 & 0.917 & 0.097 & 0.153 & -0.052 & -0.057 & -0.014 & 0.938 & 0.934 & 0.826 \\
\hline comp2 & 0.065 & 0.123 & 0.926 & 0.150 & 0.120 & -0.011 & -0.027 & -0.010 & & & \\
\hline comp3 & 0.041 & 0.092 & 0.883 & 0.172 & 0.202 & 0.005 & 0.009 & -0.004 & & & \\
\hline curr1 & -0.033 & 0.933 & 0.118 & 0.146 & 0.193 & -0.046 & 0.004 & -0.032 & 0.953 & 0.945 & 0.851 \\
\hline curr2 & -0.025 & 0.924 & 0.144 & 0.129 & 0.189 & -0.064 & -0.048 & 0.010 & & & \\
\hline curr3 & 0.014 & 0.911 & 0.092 & 0.057 & 0.143 & -0.050 & -0.069 & 0.007 & & & \\
\hline convenience1 & 0.144 & 0.097 & 0.182 & 0.884 & 0.063 & -0.052 & -0.057 & -0.004 & 0.922 & 0.922 & 0.797 \\
\hline convenience 2 & 0.157 & 0.089 & 0.167 & 0.917 & 0.108 & -0.027 & -0.031 & -0.080 & & & \\
\hline convenience 3 & 0.149 & 0.136 & 0.075 & 0.877 & 0.120 & -0.059 & -0.043 & 0.018 & & & \\
\hline sa1 & 0.094 & 0.193 & 0.163 & 0.139 & 0.836 & -0.080 & -0.109 & -0.172 & 0.921 & 0.900 & 0.751 \\
\hline $\mathrm{sa} 2$ & 0.019 & 0.187 & 0.169 & 0.144 & 0.890 & -0.098 & -0.144 & -0.032 & & & \\
\hline sa3 & 0.072 & 0.190 & 0.188 & 0.039 & 0.873 & -0.083 & -0.125 & -0.022 & & & \\
\hline Irritation 1 & 0.796 & -0.033 & -0.067 & 0.055 & 0.024 & 0.022 & 0.093 & -0.048 & 0.904 & 0.923 & 0.707 \\
\hline Irritation2 & 0.852 & -0.056 & 0.061 & 0.047 & -0.026 & -0.027 & 0.102 & -0.093 & & & \\
\hline Irritation3 & 0.801 & 0.051 & -0.023 & 0.204 & 0.055 & -0.022 & -0.004 & -0.043 & & & \\
\hline Irritation4 & 0.862 & 0.001 & 0.123 & 0.089 & 0.089 & -0.062 & 0.102 & 0.024 & & & \\
\hline Irritation5 & 0.890 & 0.006 & 0.036 & 0.073 & 0.041 & -0.008 & 0.097 & 0.059 & & & \\
\hline complaint1 & 0.162 & -0.134 & -0.084 & 0.031 & -0.142 & 0.121 & 0.833 & 0.103 & 0.865 & 0.891 & 0.731 \\
\hline complaint2 & 0.061 & 0.068 & 0.020 & -0.083 & -0.082 & 0.121 & 0.869 & 0.006 & & & \\
\hline complaint3 & 0.168 & -0.063 & -0.017 & -0.070 & -0.118 & 0.176 & 0.863 & 0.039 & & & \\
\hline Blockade1 & -0.039 & -0.070 & -0.006 & -0.067 & -0.092 & 0.843 & 0.149 & 0.195 & 0.864 & 0.879 & 0.709 \\
\hline Blockade 2 & -0.013 & -0.049 & -0.049 & -0.038 & -0.075 & 0.867 & 0.130 & 0.187 & & & \\
\hline Blockade 3 & -0.031 & -0.039 & -0.007 & -0.029 & -0.065 & 0.814 & 0.140 & 0.266 & & & \\
\hline neg1 & -0.024 & 0.024 & -0.125 & 0.010 & -0.015 & 0.206 & 0.008 & 0.827 & 0.749 & 0.822 & 0.609 \\
\hline neg2 & 0.018 & -0.043 & 0.037 & -0.011 & -0.002 & 0.170 & 0.031 & 0.828 & & & \\
\hline neg3 & -0.105 & 0.015 & 0.073 & -0.066 & -0.217 & 0.270 & 0.109 & 0.675 & & & \\
\hline
\end{tabular}

Note 1. bold for loading factor $>0.6$

Note 2. CR (Composite reliability $)=(\Sigma \text { standardized loading })^{2} /(\Sigma \text { standardized loading })^{2}+\Sigma \varepsilon j$.

Note 3. AVE (Average variance extracted $)=\Sigma\left(\right.$ standardized loading $\left.^{2}\right) / \Sigma(\text { standardized loading })^{2}+\Sigma \varepsilon j$

where $\varepsilon j$ - Indicator measurement error 
Table 3. Correlation estimates with square root of AVE

\begin{tabular}{|c|c|c|c|c|c|c|c|c|c|}
\hline constructs & mean & std. & 2 & 3 & 4 & 5 & 6 & 7 & 8 \\
\hline 1 completeness & 2.267 & 1.2790 .909 & & & & & & & \\
\hline 2 currency & 1.743 & $1.0390 .288 * *$ & 0.922 & & & & & & \\
\hline 3 access convenience & 2.617 & $1.3350 .329 * *$ & $0.262 * *$ & 0.893 & & & & & \\
\hline 4 satisfaction & 2.190 & $1.1300 .385^{* *}$ & $0.414 * *$ & $0.284 * *$ & 0.867 & & & & \\
\hline 5 Irritation & 3.733 & 0.8350 .087 & 0.001 & $0.271 * *$ & 0.115 & 0.841 & & & \\
\hline 6 complaint & 4.207 & $0.708-0.086$ & $-0.131 *$ & -0.099 & $-0.282 * *$ & $0.217 * *$ & 0.855 & & \\
\hline 7 blockade & 3.797 & $1.049-0.078$ & $-0.141 *$ & $-0.132 *$ & $-0.236 * *$ & 0.053 & 0.327 & 0.842 & \\
\hline 8 negative WOM & 3.651 & $1.014-0.047$ & -0.046 & -0.084 & $-0.202 * *$ & 0.074 & $0.159 *$ & $0.499 * *$ & 0.780 \\
\hline
\end{tabular}

Note $1 . * *: \mathrm{p}<0.01 ; *$ p $<0.05$

Note 2. the diagonal bold means square root of AVE

\subsection{Analysis and Results}

AMOS 21.0 (structural equation modeling) was used to test the hypotheses of the model. The hypotheses were analyzed to confirm the hypothesized relationships among these constructs. AMOS is well suited and simple for testing such constructs (Tsao 2013). First, the index of fit for the measurement model was examined. The criteria of chi-square $=1.706$; GFI $(0.800>0.800)$, AGFI $(0.800>0.800)$, NFI $(0.900>0.900)$, CFI $(0.901>0.900)$, and IFI $(0.902>0.900)$. Second, the index of fit for the structural model was examined. The criteria of chi-square $=2.930$; GFI $(0.802>0.800)$, AGFI $(0.892>0.800)$, NFI $(0.901>0.900)$, CFI $(0.900>0.900)$, and IFI $(0.900>0.900)$. The above are all values suggested by Hair et al. (1998). The RMSEA was also satisfactory $(0.047<0.05)$. Second, the standardized path coefficients and their statistical significance for the hypotheses in this model were estimated. The results indicated that users felt that the completeness, currency, and access convenience of ads in LINE positively impacted their satisfaction $(\beta=0.207 ; \mathrm{t}=3.883, \mathrm{p}<0.001 ; \beta=0.315 ; \mathrm{t}=$ $5.142, \mathrm{p}<0.001 ; \beta=0.122 ; \mathrm{t}=2.324, \mathrm{p}>0.05$, non-significant n.s.). Evidently, users' perceptions of higher levels of completeness, currency, and access convenience with regard to ads in LINE generally led to higher levels of satisfaction. Therefore, hypotheses 1 and 2 were supported, and hypothesis 3 was not. Second, users' satisfaction negatively impacted their harmful feelings including complaints, blockade, and NWOM regarding ads in LINE $(\beta=-0.483, \mathrm{t}=-9.716, \mathrm{p}<0.001 ; \beta=-1.424, \mathrm{t}=-16.553, \mathrm{p}<0.001 ; \beta=-1.271, \mathrm{t}=-15.028, \mathrm{p}<$ 0.001 , respectively, as shown in Table 4 ). These results demonstrated that users' satisfaction significantly affected their feelings about complaints, willing to blockade, and NWOM from ads in LINE. Higher levels of user satisfaction regarding LINE led to significantly fewer complaints, less willingness to blockade, and few NWOMs. Therefore, hypotheses 4, 5, and 6 were supported.

Table 4. Results of hypotheses with Amos

\begin{tabular}{lllrrr}
\hline & \multicolumn{2}{c}{ Path } & Estimate & t value & P \\
\hline Satisfaction & $<---$ & Completeness & 0.207 & 3.883 & $* * *$ H1 supported \\
Satisfaction & $<---$ & Currency & 0.315 & 5.142 & $* * *$ H2 supported \\
Satisfaction & $<---$ & Convenience & 0.122 & 2.324 & 0.02 H3 not supported \\
Complaint & $<---$ & Satisfaction & -0.483 & -9.716 & $* * *$ H4 supported \\
Blockade & $<---$ & Satisfaction & -1.424 & -16.553 & $* * *$ H5 supported \\
NWOM & $<---$ & Satisfaction & -1.271 & -15.028 & $* * *$ H6 supported \\
\hline
\end{tabular}

Note. $* * *: \mathrm{p}<0.001$

Subsequently, a bootstrapping approach with AMOS was used to test the indirect and direct mediating effects of satisfaction on unfavorable behavioral intentions. Bootstrapping is a technique to estimate the properties of variables from the initial observations and includes indirect effect, direct effect, and total effect. An indirect effect is the effect of one variable on another that is mediated by at least one other variable in a model. The upper and lower bounds of indirect effect exclude zero in 95\% confidence interval to show the mediating effect exists (Bollen and Stine 1990). In this paper, the indirect effects of completeness, currency, and access convenience on the complaint were characterized with $95 \%$ confidence intervals, all of which included zero. This implies that the user satisfaction with ads in LINE did not have mediating effects on complaint. Second, the indirect effects of completeness, currency, and access convenience on the blockade were characterized with $95 \%$ confidence intervals, where the last two of them excluded zero. This implies that user satisfaction with ads in LINE had mediating effects on blockade. The upper and lower bounds of direct effect excluded zero in 95\% confidence interval to prove the partial mediator; otherwise, the full mediator. The direct effect of completeness and currency included zero. Thus, the result showed that user satisfaction had full mediating effects between the completeness and currency of information and blockade, as detailed in Table 5. Therefore, Hypotheses 11a and 11b, i.e., satisfaction has mediating effects on blockade, were proved. Finally, following the same steps, the effects of completeness, currency, and access convenience on the 
NWOM were characterized with $95 \%$ confidence intervals. User satisfaction had full mediating effects between the completeness and currency of information and NWOM. Therefore, Hypotheses 12a and 12b, i.e., satisfaction has mediating effects on NWOM, were proved.

Table 5. Result satisfaction of mediating indirect and direct effects on unfavorable behavioral intentions

\begin{tabular}{|c|c|c|c|c|c|c|}
\hline \multirow{2}{*}{ constructs } & \multirow{2}{*}{$\begin{array}{c}\text { point } \\
\text { estimate }\end{array}$} & \multicolumn{2}{|c|}{ Product of Coefficients } & \multicolumn{2}{|c|}{$\begin{array}{l}\text { Bootstrapping } \\
\text { Bias-Corrected 95\% CI }\end{array}$} & \multirow[t]{2}{*}{ result } \\
\hline & & SE & $\mathrm{Z}$ & Lower & $\begin{array}{l}\text { Mediating } \\
\text { effect }\end{array}$ & \\
\hline $\begin{array}{l}\text { Total effect } \\
\text { sustainability }\end{array}$ & 0.110 & 0.050 & 2.200 & 0.012 & 0.208 & \\
\hline enjoyment & 0.034 & 0.088 & 0.386 & -0.139 & 0.206 & \\
\hline reputation & 0.108 & 0.075 & 1.440 & -0.039 & 0.255 & \\
\hline economic benefit & & 0.124 & 0.056 & 2.214 & 0.015 & \\
\hline $\begin{array}{l}\text { Direct effec } \\
\text { sustainability }\end{array}$ & 0.068 & 0.047 & 1.447 & -0.025 & 0.160 & \\
\hline $\begin{array}{l}\text { enjoyment } \\
\text { reputation }\end{array}$ & -0.114 & 0.085 & -1.341 & -0.281 & 0.053 & \\
\hline $\begin{array}{l}\text { economic benefit } \\
\text { Indirect eff }\end{array}$ & & 0.133 & 0.052 & 2.558 & 0.031 & \\
\hline $\begin{array}{l}\text { sustainability } \\
\text { total effect }\end{array}$ & & 0.042 & 0.028 & 1.500 & -0.015 & \\
\hline completeness & -0.295 & 0.171 & -1.725 & -0.640 & -0.008 exist & \\
\hline currency & -0.448 & 0.251 & -1.785 & -0.971 & -0.007 exist & \\
\hline $\begin{array}{l}\text { convenience } \\
\text { indirect effect }\end{array}$ & -0.174 & 0.125 & -1.392 & -0.489 & 0.016 not exist & \\
\hline completeness & -0.295 & 0.171 & -1.725 & -0.640 & -0.008 exist & \\
\hline currency & -0.448 & 0.251 & -1.785 & -0.971 & -0.007 exist & \\
\hline $\begin{array}{l}\text { convenience } \\
\text { direct effect }\end{array}$ & -0.174 & 0.125 & -1.392 & -0.489 & 0.016 not exist & \\
\hline completeness & -0.06 & -0.175 & 0.343 & -0.175 & 0.029 full & H11a \\
\hline $\begin{array}{l}\text { currency } \\
\text { convenience }\end{array}$ & -0.131 & -0.309 & 0.424 & -0.309 & 0.071 full & $\mathrm{H} 11 \mathrm{~b}$ \\
\hline & & & IWOM & & & \\
\hline total effect & & & & & & \\
\hline completeness & -0.263 & 0.150 & -1.753 & -0.040 & -0.040 exist & \\
\hline currency & -0.400 & 0.212 & -1.887 & -0.076 & -0.076 exist & \\
\hline $\begin{array}{l}\text { convenience } \\
\text { indirect effect }\end{array}$ & -0.155 & 0.107 & -1.449 & 0.004 & 0.004 not exist & \\
\hline completeness & -0.263 & 0.150 & -1.753 & -0.260 & -0.040 exist & \\
\hline currency & -0.400 & 0.212 & -1.887 & -0.398 & -0.076 exist & \\
\hline $\begin{array}{l}\text { convenience } \\
\text { direct effect }\end{array}$ & -0.155 & 0.107 & -1.449 & -0.203 & 0.004 not exist & \\
\hline completeness & 0.089 & -0.035 & -2.543 & -0.035 & 0.240 full & $\mathrm{H} 12 \mathrm{a}$ \\
\hline $\begin{array}{l}\text { currency } \\
\text { convenience }\end{array}$ & 0.222 & -0.017 & -13.059 & -0.017 & 0.468 full & $\mathrm{H} 12 \mathrm{~b}$ \\
\hline
\end{tabular}

Note. SE: standard error

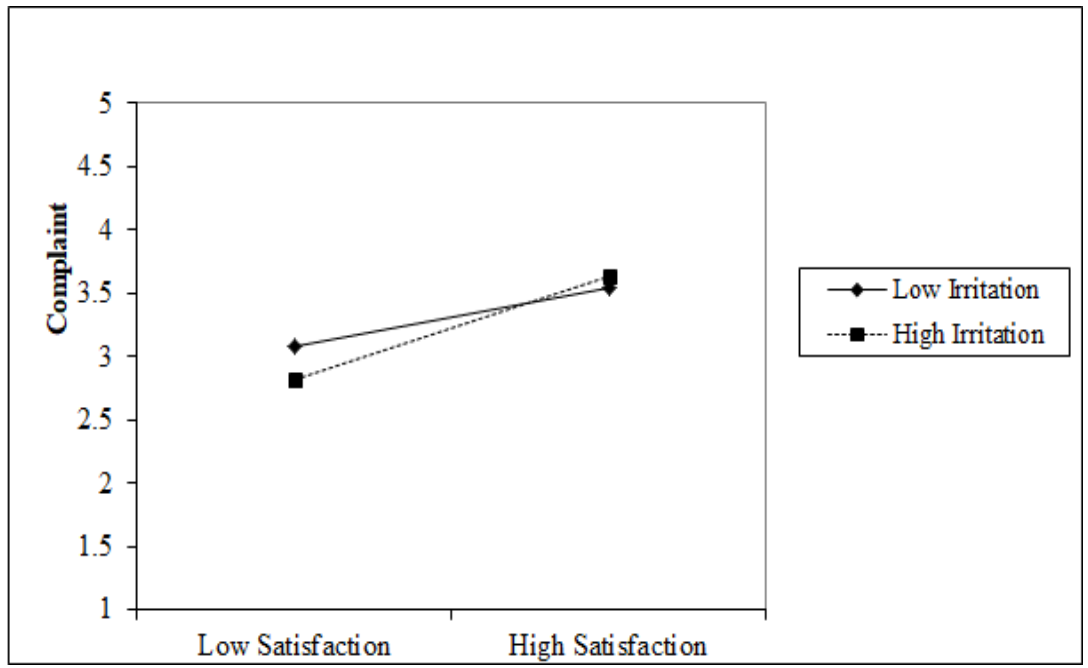

Figure 2. Moderating effect of people' irritation between satisfaction and ads complaint 
Finally, irritation was assessed as a moderator of unfavorable behavioral intentions toward the ads in LINE. Three significant interactions (saXirri) of satisfaction and irritation on complaint $(\beta=-0.095, t=-2.914, p$ $<0.01)$ and blockade $(\beta=0.144, t=4.451, p<0.001)$ yielded significantly moderated effects, but those of NWOM did not $(\beta=0.086, t=1.816, p>0.05$, as shown in Figure 4). With high advertising irritation, users presented high satisfaction with the ads that would increase complaint (Figure 2). With high advertising irritation, users' demonstrated high satisfaction with the ads that would rapidly raise blockade (Figure 3) Therefore, hypotheses 7 and 8 were supported.



Figure 3. Moderating effect of people' irritation between satisfaction and ads blockade

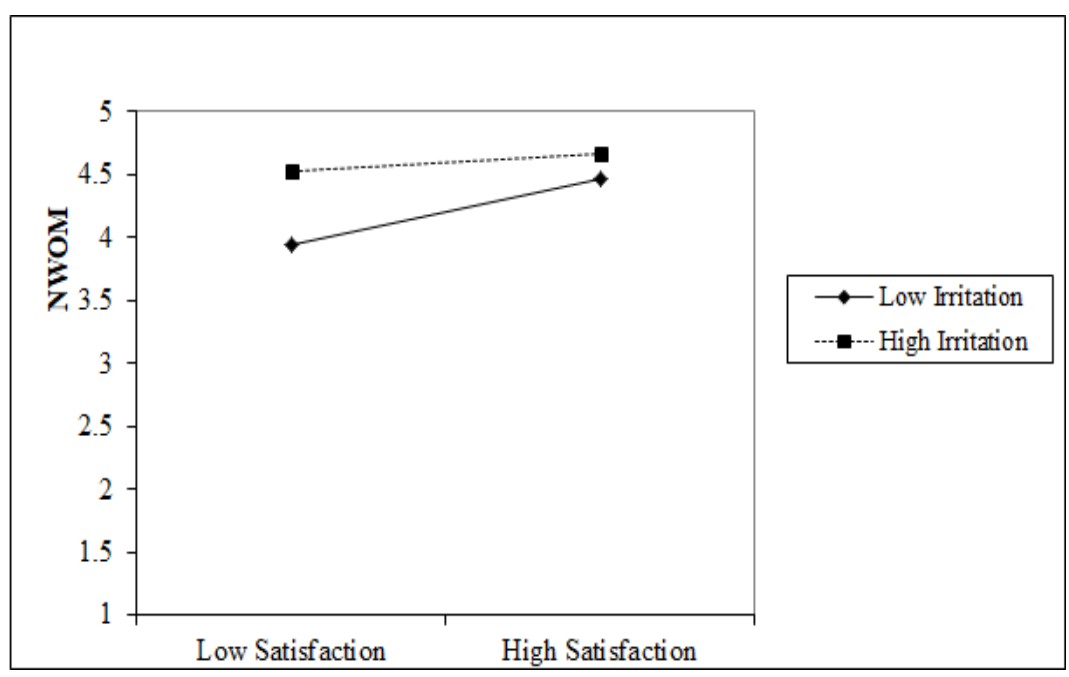

Figure 4. Moderating effect of people' irritation between satisfaction and ads NWOM

\section{Conclusion}

\subsection{Discussion and Contribution}

On the basis of an analysis of prior literature, a moderated mediated model is developed in this study to explore the relationships among IQ (as indicated by completeness and currency), access convenience, satisfaction, irritation, and unfavorable behavioral intentions about ads in LINE. The findings reinforces that IQ dimensions of ads' such as completeness and currency of information decrease uncomfortable feelings through user satisfaction; it appears to have an important impact that ever found; users felt that complete, current, and conveniently accessible ads used in LINE increased their satisfaction. Satisfaction was also confirmed to have a full mediating effect in the causal pathway from completeness and currency to unfavorable behavioral intentions. A moderator, irritation, was found to weaken the strength of the relationships between satisfaction and unfavorable behavioral intentions. Therefore, irritation is still an annoyance factor to make users uncomfortable. 
In the context of LINE usage in Taiwan, related studies on unfavorable behavioral intentions have frequently been based on service failures (Smith and Bolton 2002; Zeithaml et al. 1996). Baker and Crompton (2000) found that tourists' negative feeling produced an unfavorable judgment. However, few studies have evaluated satisfaction of ads to have a mediating effect on complaints, blockade, and NWOM, which is moderated by irritation. As expected mostly, the results support the hypotheses that the completeness and currency of ads in LINE have positive impacts on user unfavorable behavioral intentions through satisfaction.

\subsection{Implications and Practice for Research}

Ads characteristics (completeness and currency of information) and access convenience decrease the unfavorable behavioral intentions of LINE through satisfaction, to an extent moderated by irritation. Considering the current discussion concerning the sources of unfavorable behavioral intentions toward the ads in social communication applications, such as the ads in LINE, the results prove that users' satisfaction is a bridge between the IQ of ads in LINE and their unfavorable behavioral intentions (such as complaints, blockade, and NWOM), especially with the irritation of ads to annoy them. From the managerial perspective, the findings of this research should be considerably helpful in a series of chains in ads of LINE, such as enterprises should know customers are dissatisfied with or disappointed by the promotion's offerings of ads. The paper theoretically extends the applicability of the ads in LINE to increase satisfaction and decrease unfavorable behavioral intentions and fills the gap in the current advertising literature. Compared with prior IS success studies that mainly focus on the positive relationships among these dimensions, this study examines the mediating effects among these negative feelings and highlights how quality and convenience play roles in the IS post-adoption outline. As long as users are satisfied with ads containing complete and updated information, in addition to access convenience, they will have favorable behavioral intentions toward the ads without complain, blockade, or say negative words to others; this can lead to the popularization of the ads in LINE. Boateng et al. (2016) implied that targeting customers have the potential for reducing the negative effect of irritation toward mobile advertising.

\subsection{Managerial Implications}

Ads (Bogart 1985) or pop-up ads (Edwards et al. 2002), pre-roll video ads (Campbell et al. 2017) were viewed as annoying media that are directly related to feelings of irritation and avoidance behaviors. Although many existing studies have explored the favorable behavioral intentions, empirical studies have not done much to confirm that irritating ads can increase the perception of unfavorable behavioral intentions. This conclusion adds a new path from IQ through satisfaction to attenuate users' unfavorable behavioral intentions with less ad irritation. Such findings may enrich the practical perspective; the findings agree that user satisfaction is an important mediator, like bridge to connect both sides, of a user's favorable (Chang and Polonsky 2012) and unfavorable intentions (Zeithaml et al. 1996; Smith and Bolton 2002). Originally, ads are annoying objects that irritate people unless the content of the ads is needed. The advertisers or creators who create ads to promote products should be cautious because people's unfavorable experiences may lead to severe consequences. The mobile network designers should design the network to be easily accessible. Within the context of this study, user satisfaction mediates the relationship between IQ dimensions such as completeness and currency and user intentions such as blockade and NWOM. User satisfaction is a bridge connecting IQ to blockade and NWOM. This research is important as it clarifies that ads should be eye-catching, informative, and current to arouse users' interest to click on them. Companies that advertise or intend to promote their products and services through LINE can realize effective and efficient promotion by adhering to the findings of the current study. Managers need to deal ads carefully; they should deliver ads that are useful and relevant in the moment; the size of ads should be size and float on the screen without irritating; sending touching short films to catch users' eyes may soften negative unfavorable behavioral intentions, especially in social media such as LINE. Therefore, the present study successfully evaluates a moderated and mediated model to explore factors affecting ads in LINE for academics.

\subsection{Limitations and Future Works}

Although these findings provide meaningful implications for ads in LINE, this study also has several limitations that need to be overcome. Considering control variable, Chu et al. (2003) found that educational level was significantly related to job satisfaction; this may be explored in the future. Moreover, this study presents only a sample of factors affecting unfavorable behavioral intentions through satisfaction as moderated by irritation. The results still require further verification. For example, the access convenience of ads was found to have a slight impact on satisfaction. This could be because convenience should be inherent in the Internet world and the LINE users did not mention. Second, substantial efforts were made to explore the relationship among these important factors affecting unfavorable behavioral intentions; however, considerable work is still required to fully explore 
them. User satisfaction was not found to have a mediating effect on the respective relationships between completeness, currency, and access convenience and the users' intention to complain; this may be because the users tend to keep their dissatisfaction to themselves rather than expressing it. In other words, the users were accustomed to saying nothing. This aspect needs to be explored further. Finally, the irritation toward ads in LINE influences user satisfaction; this is an important driving force that explains why ads or pop-up ads may be negatively related to blockade and avoidance behaviors (Bogart, 1985; Edwards et al. 2002) or positively related to willingness to click for further query. These factors are also interesting phenomena to explore further.

\section{References}

Altuna, O. K., \& Konuk, F. A. (2009). Understanding consumer attitudes toward mobile advertising and its impact on consumers' behavioral intention: Across-market comparison of U.S. and Turkish consumers. International Journal of Mobile Marketing, 4(2), 43-51.

Armstrong, J. S., \& Overton, T. S. (1977). Estimating nonresponse bias in mail surveys. Journal of Marketing Research (JMR), 14(3), 396-402. https://doi.org/10.1177/002224377701400320

Bai, B., Law, R., \& Wen, I. (2008). The impact of website quality on customer satisfaction and purchase intentions: Evidence from Chinese online visitors. International Journal of Hospitality Management, 27(3), 391-402. https://doi.org/10.1016/j.ijhm.2007.10.008

Baker, D. A., \& Crompton, J. L. (2000). Quality, satisfaction and behavioral intentions. Annals of Tourism Research, 27(3), 785-804. https://doi.org/10.1016/S0160-7383(99)00108-5

Bauer, R. A., \& Greyser, S. A. (1968). Advertising in America, the consumer view. Harvard University.

Bharati, P., \& Chaudhury, A. (2004). An empirical investigation of decision-making satisfaction in web-based decision support systems. Decision Support Systems, 37(2), 187-197. https://doi.org/10.1016/S0167-9236(03)00006-X

Boateng, H., Okoe, A. F., \& Omane, A. B. (2016). Does personal innovativeness moderate the effect of irritation on consumers' attitudes towards mobile advertising? Journal of Direct, Data and Digital Marketing Practice, 17(3), 201-210. https://doi.org/10.1057/dddmp.2015.53

Bogart, L. (1985). War of the words: Advertising in the year 2010. Across the Board, 1.

Bollen, K. A., \& Stine, R. (1990). Direct and indirect effects: Classical and bootstrap estimates of variability, Sociological Methodology, 20, 115-140. https://doi.org/10.2307/271084

Bronner, F., \& Neijens, P. (2006). Audience experiences of media context and embedded advertising: A comparison of eight media. International Journal of Market Research, 48(1), 81-100. https://doi.org/10.1177/147078530604800106

Campbell, C., Mattison Thompson, F., Grimm, P. E., \& Robson, K. (2017). Understanding why consumers don't skip pre-roll video ads. Journal of Advertising, 46(3), 411-423. https://doi.org/10.1080/00913367.2017.1334249

Chang, Y. W., \& Polonsky, M. J. (2012). The influence of multiple types of service convenience on behavioral intentions: The mediating role of consumer satisfaction in a Taiwanese leisure setting. International Journal of Hospitality Management, 31(1), 107-118. https://doi.org/10.1016/j.ijhm.2011.05.003

Chi, C. G., \& Gursoy, D. (2009). Employee satisfaction, customer satisfaction, and financial performance: An empirical examination. International Journal of Hospitality Management, 28(2), 245-253. https://doi.org/10.1016/j.ijhm.2008.08.003

Cho, C. H. (2004). Why do people avoid advertising on the Internet? Journal of Advertising, 33(4), 89-97. https://doi.org/10.1080/00913367.2004.10639175

Chu, C. I., Hsu, H. M., Price, J. L., \& Lee, J.Y. (2003). Job satisfaction of hospital nurses: An empirical test of a causal model in Taiwan. International Nursing Review, 50(3), 176-182. https://doi.org/10.1046/j.1466-7657.2003.00165.x

Chu, S. C. (2011). Viral advertising in social media: Participation in Facebook groups and responses among college-aged users. Journal of Interactive Advertising, 12(1), 30-43. https://doi.org/10.1080/15252019.2011.10722189

Chuang, S. C., Tsai, C. C., Cheng, Y. H., \& Sun, Y. C. (2009). The effect of terminologies on attitudes toward advertisements and brands: Consumer product knowledge as a moderator. Journal of Business and 
Psychology, 24(4), 485-491. https://doi.org/10.1007/s10869-009-9122-4

Cole, S. T., \& Illum, S. F. (2006). Examining the mediating role of festival visitors' satisfaction in the relationship between service quality and behavioral intentions. Journal of Vacation Marketing, 12(2), 160-173. https://doi.org/10.1177/1356766706062156

Colwell, S. R., Aung, M., Kanetkar, V., \& Holden, A. L. (2008). Toward a measure of service convenience: Multiple-item scale development and empirical test. Journal of Services Marketing, 22(2), 160-169. https://doi.org/10.1108/08876040810862895

Correa, T., Hinsley, A. W., \& De Zuniga, H. G. (2010). Who interacts on the web? The intersection of users' personality and social media use. Computers in Human Behavior, 26(2), 247-253. https://doi.org/10.1016/j.chb.2009.09.003

Daud, D., \& Fang, O. H. (2017). Acceptance of information system modules in logistics program: Perceptions from logistics and supply chain undergraduate students. Canadian Social Science, 13(5), 14-21.

Davis, F. D., Bagozzi, R. P., \& Warshaw, P. R. (1992). Extrinsic and intrinsic motivation to use computers in the workplace 1. Journal of Applied Social Psychology, 22(14), 1111-1132. https://doi.org/10.1111/j.1559-1816.1992.tb00945.x

DeLone, W. H., \& McLean, E. R. (1992). Information systems success: The quest for the dependent variable. Information Systems Research, 3(1), 60-95. https://doi.org/10.1287/isre.3.1.60

Dubé, L., Renaghan, L. M., \& Miller, J. M. (1994). Measuring customer satisfaction for strategic management. Cornell Hotel and Restaurant Administration Quarterly, 35(1), 39-47.

Ducoffe, R. H. (1996). Advertising value and advertising on the web. Journal of Advertising Research, 36(5), 21-35.

Edwards, S. M., Li, H., \& Lee, J. H. (2002). Forced exposure and psychological reactance: antecedents and consequences of the perceived intrusiveness of pop-up ads. Journal of Advertising, 31(3), 83-96. https://doi.org/10.1080/00913367.2002.10673678

Erkan, I., \& Evans, C. (2016). The influence of eWOM in social media on consumers' purchase intentions: An extended approach to information adoption. Computers in Human Behavior, 61, 47-55. https://doi.org/10.1016/j.chb.2016.03.003

Finn, A., Wang, L., \& Frank, T. (2009). Attribute perceptions, customer satisfaction and intention to recommend e-services. Journal of Interactive Marketing, 23(3), 209-220. https://doi.org/10.1016/j.intmar.2009.04.006

Fornell, C., \& Larcker, D. F. (1981). Evaluating structural equation models with unobservables and measurement error. Journal of Marketing Research, 18(1), 39-50. https://doi.org/10.1177/002224378101800104

Fornell, C., Johnson, M. D., Anderson, E. W., Cha, J., \& Bryant, B. E. (1996). The American customer satisfaction index: Nature, purpose, and findings. Journal of Marketing, 60(4), 7-18. https://doi.org/10.2307/1251898

Grudzień, Ł., \& Hamrol, A. (2016). Information quality in design process documentation of quality management systems. International Journal of Information Management, 36(4), 599-606. https://doi.org/10.1016/j.jinfomgt.2016.03.011

Ha, L. (1996). Advertising clutter in consumer magazines: Dimensions and effects. Journal of Advertising Research, 36(4), 76-85.

Ha, Y., \& Im, H. (2012). Role of web site design quality in satisfaction and word of mouth generation. Journal of Service Management, 23(1), 79-96. https://doi.org/10.1108/09564231211208989

Hair, J. F., Anderson, R. E., Tatham, R. L., \& Black, W. C. (1998). Multivariate data analysis. Upper Saddle River.

Hennig-Thurau, T., Gwinner, K. P., Walsh, G., \& Gremler, D. D. (2004). Electronic word-of-mouth via consumer-opinion platforms: What motivates consumers to articulate themselves on the Internet? Journal of Interactive Marketing, 18(1), 38-52. https://doi.org/10.1002/dir.10073

Hsieh, C. C., Kuo, P. L., Yang, S. C., \& Lin, S. H. (2010). Assessing blog-user satisfaction using the expectation and disconfirmation approach. Computers in Human Behavior, 26(6), 1434-1444. https://doi.org/10.1016/j.chb.2010.04.022

Jin, C. H., \& Villegas, J. (2006). Consumer responses to advertising on the Internet: The effect of individual 
difference on ambivalence and avoidance. CyberPsychology \& Behavior, 10(2), 258-266. https://doi.org/10.1089/cpb.2006.9960

Kalamas, M., Laroche, M., \& Makdessian, L. (2008). Reaching the boiling point: Consumers' negative affective reactions to firm-attributed service failures. Journal of Business Research, 61(8), 813-824. https://doi.org/10.1016/j.jbusres.2007.09.008

Kang, Y. S., Hong, S., \& Lee, H. (2009). Exploring continued online service usage behavior: The roles of self-image congruity and regret. Computers in Human Behavior, 25(1), 111-122. https://doi.org/10.1016/j.chb.2008.07.009

Kim, B., \& Han, I. (2011). The role of utilitarian and hedonic values and their antecedents in a mobile data service environment. Expert Systems with Applications, 38(3), 2311-2318. https://doi.org/10.1016/j.eswa.2010.08.019

Kim, J., Jin, B., \& Swinney, J. L. (2009). The role of etail quality, e-satisfaction and e-trust in online loyalty development process. Journal of Retailing and Consumer Services, 16(4), 239-247. https://doi.org/10.1016/j.jretconser.2008.11.019

Kohli, A. K., \& Jaworski, B. J. (1990). Market orientation: the construct, research propositions, and managerial implications. The Journal of Marketing, 54(2), 1-18. https://doi.org/10.1177/002224299005400201

Kuvaas, B. (2006). Performance appraisal satisfaction and employee outcomes: Mediating and moderating roles of work motivation. The International Journal of Human Resource Management, 17(3), 504-522. https://doi.org/10.1080/09585190500521581

Lai, F., Griffin, M., \& Babin, B. J. (2009). How quality, value, image, and satisfaction create loyalty at a Chinese telecommunications. Journal of Business Research, 62(10), 980-986. https://doi.org/10.1016/j.jbusres.2008.10.015

Laumer, S., Maier, C., \& Weitzel, T. (2017). Information quality, user satisfaction, and the manifestation of workarounds: A qualitative and quantitative study of enterprise content, management system users. European Journal of Information Systems, 26(4), 333-360. https://doi.org/10.1057/s41303-016-0029-7

Lee, J., Kim, S., \& Ham, C. D. (2016). A double-edged sword? Predicting consumers' attitudes toward and sharing intention of native advertising on social media. American Behavioral Scientist, 60(12), 1425-1441. https://doi.org/10.1177/0002764216660137

Lin, C. (1999). Online-service adoption likelihood. Journal of Advertising Research, 39(2), 79-89.

Litvin, S. W., Goldsmith, R. E., \& Pan, B. (2008). Electronic word-of-mouth in hospitality and tourism management. Tourism Management, 29(3), 458-468. https://doi.org/10.1016/j.tourman.2007.05.011

Liu, Y., \& Jang, S. S. (2009). Perceptions of Chinese restaurants in the US: What affects customer satisfaction and behavioral intentions? International Journal of Hospitality Management, 28(3), 338-348. https://doi.org/10.1016/j.ijhm.2008.10.008

Loureiro, S. M. C. (2018). Tell what you want but do not irritate me: A senior perspective about advertising. Journal of Promotion Management, 24(2), 198-214. https://doi.org/10.1080/10496491.2017.1360825

Luna Cortés, G., \& Royo Vela, M. (2013). The antecedents of consumers' negative attitudes toward SMS advertising: A theoretical framework and empirical study. Journal of Interactive Advertising, 13(2), 109-117. https://doi.org/10.1080/15252019.2013.826553

Maxham III, J. G., \& Netemeyer, R. G. (2002). Modeling customer perceptions of complaint handling over time: The effects of perceived justice on satisfaction and intent. Journal of Retailing, 78(4), 239-252. https://doi.org/10.1016/S0022-4359(02)00100-8

Nakagami, E., Xie, B., Hoe, M., \& Brekke, J. S. (2008). Intrinsic motivation, neurocognition and psychosocial functioning in schizophrenia: Testing mediator and moderator effects. Schizophrenia Research, 105(1-3), 95-104. https://doi.org/10.1016/j.schres.2008.06.015

Ngai, E. W., Tao, S. S., \& Moon, K. K. (2015). Social media research: Theories, constructs, and conceptual frameworks. International Journal of Information Management, 35(1), 33-44. https://doi.org/10.1016/j.ijinfomgt.2014.09.004

Nunnally, J. C., \& Bernstein, I. H. (1994). Psychometric Theory. McGraw-Hill, New York, NY.

Okazaki, S. (2004). How do Japanese consumers perceive wireless ads? A multivariate analysis. International 
Journal of Advertising, 23(4), 429-454. https://doi.org/10.1080/02650487.2004.11072894

Oliver, R. L. (1997). Satisfaction: A behavioral perspective on the consumer. McGraw-Hill, New York.

Podsakoff, P. M., MacKenzie, S. B., Lee, J. Y., \& Podsakoff, N. P. (2003). Common method biases in behavioral research: A critical review of the literature and recommended remedies. Journal of Applied Psychology, 88(5), 879-903. https://doi.org/10.1037/0021-9010.88.5.879

Ramanathan, U., Subramanian, N., \& Parrott, G. (2017). Role of social media in retail network operations and marketing to enhance customer satisfaction. International Journal of Operations and Production Management, 37(1), 105-123. https://doi.org/10.1108/IJOPM-03-2015-0153

Richins, M. L. (1983). Negative word-of-mouth by dissatisfied consumers: A pilot study. Journal of Marketing, 47(1), 68-78. https://doi.org/10.1177/002224298304700107

Rohm, A., D. Kaltcheva, V., \& R.Milne, G. (2013). A mixed-method approach to examining brand-consumer interactions driven by social media. Journal of Research in Interactive Marketing, 7(4), 295-311. https://doi.org/10.1108/JRIM-01-2013-0009

Sanchez-Franco, M. J., Ramos, A. F. V., \& Velicia, F. A. M. (2009). The moderating effect of gender on relationship quality and loyalty toward internet service providers. Information \& Management, 46(3), 196-202. https://doi.org/10.1016/j.im.2009.02.001

Scaglione, F. (1988). Two-way communication: Tapping into gripes and profits. Management Review, 77, 51-53.

Seiders, K., Voss, G. B., \& Grewal, D. (2005). Do satisfied customers buy more? Examining moderating influences in a retailing context. Journal of Marketing, 69(4), 26-43.

https://doi.org/10.1509/jmkg.2005.69.4.26

Singh, J. (1988). Consumer complaint intentions and behavior: Definitional and taxonomical issues. Journal of Marketing, 52(1), 93-107. https://doi.org/10.1177/002224298805200108

Singh, J., \& Widing, R. E. (1991). What occurs once consumers complain? A theoretical model for understanding satisfaction/dissatisfaction outcomes of complaint responses. European Journal of Marketing, 25(5), 30-46. https://doi.org/10.1108/03090569110140489

Singh, J., \& Wilkes, R. E. (1996). When consumers complain: A path analysis of the key antecedents of consumer complaint response estimates. Journal of the Academy of Marketing Science, 24(4), 350-365. https://doi.org/10.1177/0092070396244006

Smith, A. K., \& Bolton, R. N. (2002). The effect of customers' emotional responses to service failures on their recovery effort evaluations and satisfaction judgments. Journal of the Academy of Marketing Science, 30(1), 5-23. https://doi.org/10.1177/03079450094298

Soriano, R. D. (2002). Customers' expectations factors in restaurants. International Journal of Quality and Reliability Management, 19(8-9), 1055-1067. https://doi.org/10.1108/02656710210438122

Srivastava, A., Avan, B. I., Rajbangshi, P., \& Bhattacharyya, S. (2015). Determinants of women's satisfaction with maternal health care: A review of literature from developing countries. BMC Pregnancy and Childbirth, 15(1), 97-108. https://doi.org/10.1186/s12884-015-0525-0

Srivastava, M., \& Kaul, D. (2014). Social interaction, convenience and customer satisfaction: The mediating effect of customer experience. Journal of Retailing and Consumer Services, 21(6), 1028-1037. https://doi.org/10.1016/j.jretconser.2014.04.007

Stevens, P., Knutson, B., \& Patton, M. (1995). DINESERV: A tool for measuring service quality in restaurant. Cornell Hotel and Restaurant Administration Quarterly, 36(2), 56-60. https://doi.org/10.1177/001088049503600226

$\mathrm{Su}, \mathrm{W}$. B. (2018). The number of monthly active users in Line has grown to 19 million, and the service data has been revealed! Retrieved from https://www.ithome.com.tw/news/121717

Tsang, M. M., Ho, S. C., \& Liang, T. P. (2004). Consumer attitudes toward mobile advertising: An empirical study. International Journal of Electronic Commerce, 8(3), 65-78. https://doi.org/10.1080/10864415.2004.11044301

Tsao, W. Y. (2013). The fitness of product information: Evidence from online recommendations. International Journal of Information Management, 33(1), 1-9. https://doi.org/10.1016/j.ijinfomgt.2012.04.003

Tsao, W. Y. (2014). Enhancing competitive advantages: The contribution of mediator and moderator on 
stickiness in the LINE. Journal of Retailing and Consumer Services, 21(6), 933-941. https://doi.org/10.1016/j.jretconser.2014.08.011

Tsao, W. Y. (2018). An assessment of propagation stickers in LINE services to promote: Toward a new model of diffusion theory. Journal of Promotion Management, 25(1), 20-42. https://doi.org/10.1080/10496491.2018.1427654

Udo G. J., Bagchi, K. K., \& Kirs, P. J. (2010). An assessment of customers' e-service quality perception, satisfaction and intention. International Journal of Information Management, 30(6), 481-492. https://doi.org/10.1016/j.ijinfomgt.2010.03.005

Ünal, S., Ercis, A., \& Keser, E. (2011). Attitudes towards mobile advertising-A research to determine the differences between the attitudes of youth and adults. Procedia-Social and Behavioral Sciences, 24, 361-377. https://doi.org/10.1016/j.sbspro.2011.09.067

Voorhees, C. M. \& Brady, M. K. (2005). A service perspective on the drivers of complaint intentions. Journal of Service Research, 8(2), 192-204. https://doi.org/10.1177/1094670505279702

Waller, D. S. (2006). A proposed response model for controversial advertising. Journal of Promotion Management, 11(2-3), 3-15. https://doi.org/10.1300/J057v11n02_02

Wu, I. L., \& Huang, C. Y. (2015). Analyzing complaint intentions in online shopping: The antecedents of justice and technology use and the mediator of customer satisfaction. Behaviour \& Information Technology, 34(1), 69-80. https://doi.org/10.1080/0144929X.2013.866163

$\mathrm{Wu}, \mathrm{L}$. (2013). The antecedents of customer satisfaction and its link to complaint intentions in online shopping: An integration of justice, technology, and trust. International Journal of Information Management, 33(1), 166-176. https://doi.org/10.1016/j.ijinfomgt.2012.09.001

Yen, Y. S. (2013). Exploring perceived value in social networking sites: The mediation of customer satisfaction. International Journal of Computer and Information Technology, 2(3), 386-391.

Ylitalo, J. (2009). Controlling for common method variance with partial least squares path modeling. http://salserver.org.aalto.fi/vanhat_sivut/Opinnot/Mat-2.4108/pdf-files/eyli09b.pdf

Yoon, C., \& Kim, S. (2007). Convenience and TAM in a ubiquitous computing environment: The case of wireless LAN. Electronic Commerce Research and Applications, 6(1), 102-112.

Zeithaml, V. A., Berry, L. L., \& Parasuraman, A. (1996). The behavioral consequences of service quality. Journal of Marketing, 60(2), 31-46.

Zhang, Z. (2010). Feeling the sense of community in social networking usage. Engineering Management, IEEE Transactions, 57(2), 225-239.

\section{Questionnaire}

Completeness [from Kim and Han's (2011) to indicate the degree of users' feelings about all the required information of ads, five-point Likert type scale]

1. The ads will provide me with a complete set of information.

2. The ads will produce comprehensive information.

3. The ads will provide me with all the information I need.

Currency [from Kim and Han's (2011) to indicate the degree of users' feelings the ads to be up to date, five-point Likert type scale]

1. The ads will provide me with the most recent information.

2. The ads will present the most current information.

3. The information from the ads will be always up to date.

Access convenience [from Seiders et al. (2005) to indicate the degree of users' access the ads with less time and effort, five-point Likert type scale]

1. It is easy to get the ads. 
2. It does not take much time to get the ads.

3. I can easily figure out the ads.

Irritation [from Edwards et al. (2002) to indicate the degree of users been interrupted by the ads, five-point Likert type scale]

I think that the ad is

1. Infuriating

2. Phony

3. Annoying

4. Bothersome

5. Disturbing

Satisfaction [from Seiders et al. (2005) to indicate the degree of users' positive feelings about the ads, five-point Likert type scale]

1. I am pleased with the overall ads.

2. Accessing ads is a delightful experience.

3. I am completely satisfied with the ads.

Complaint [from Sanchez-Franco et al. (2009) to indicate the degree of users' negative experiences of the ads, five-point Likert type scale]

1. I will complain to other members about the ads.

2. I will complain to others about the ads.

3. I will complain enterprise of LINE about the ads.

Blockade [from Kim et al. (2009) to indicate the degree of users' willing the blockade the ads, five-point Likert type scale]

1. I intend to blockade the ads in the future.

2. I will blockade the ads.

3. I plan to blockade the ads.

Negative WOM [from Kalamas et al. (2008) to indicate the degree of users to tell other users or potential users about the ads negatively, five-point Likert type scale]

1. I will not recommend the ads to my friends and acquaintances.

2. I will discourage friends and acquaintances to spread the ads.

3. I will not tell the ads in LINE to my friends and acquaintances for ads.

\section{Copyrights}

Copyright for this article is retained by the author(s), with first publication rights granted to the journal.

This is an open-access article distributed under the terms and conditions of the Creative Commons Attribution license (http://creativecommons.org/licenses/by/4.0/). 